\title{
CORONAVIRUS CHALLENGES \& SOLUTIONS IN ISLAMIC PERSPECTIVE
}

Dr. Farhat Aziz*

Dr. Samina Saadia**

\begin{abstract}
People infected with the corona virus in Pakistan is increasing day by day. Although the government has taken timely precautions and security measures, the death toll from the virus is much lower than in other countries, but the reality is that the lockdown that has been going on for weeks in most parts of the country The economy has been hit hard. Due to the closure of various industries and restrictions on transportation, about 19 million people have lost their jobs, $70 \%$ of whom are from Punjab province. Among those most affected by the lockdown restrictions are employees of small and medium-sized enterprises, businesses and companies (SMEs) and hard-working daily wage earners. The government has allocated Rs. 144 billion under the Ehsas Emergency Cash Program to provide financial assistance to the unemployed. However, this is not a permanent solution to the problem. The government's first priority should be to stabilize the economy in the light of various economic indicators. The truth is that due to the abundance of problems, scarcity of resources and extreme poverty, a country of 220 million people cannot afford a long lockdown. The purpose of this article is to how to deal with these disturbing situations with a believing character and a positive attitude.
\end{abstract}

Keywords: Coronavirus, Challenges, Solutions, Islamic Perspective

\section{Introduction}

On December 6, four residents of Wuhan (capital of Hubei Province) in central China approached Dr. Zheng Jixian with a fever, cough, and difficulty breathing. Dr. Zheng discovered a mysterious type of pneumonia in these patients. In those days, Dr. Lee Wenliang of Wuhan Central Hospital also warned people about a new virus through social media. This question cannot be answered definitively at this time. But what has been happening since then is becoming news for us and history for generations to come. ${ }^{1}$

\footnotetext{
* Associate Professor, Lahore College for Women University, Lahore - Pakistan farhatfcc27@gmail.com

** Assistant Professor, Sheikh Zayed Islamic Center, University of the Punjab, Lahore Pakistandr.saminasaadia@gmail.com
} 
The number of patients infected with the new virus began to rise in Wuhan. Most of the victims belonged to a seafood market, where fish and other marine animals were eaten, as well as a variety of bears, rats, monkeys, snakes, squirrels, bats, crocodiles, dogs, donkeys, foxes, pigs. Meat of turtles and wolves was also available. A few days later, China closed the market and took several effective steps. But the virus spread like wildfire around the world. From the East to the West, there is hardly a country that is safe from it. So far, about 500,000 people have been infected with the disease (named COVID-19). More than 100,000 of these victims have died in every region of the world, and the number is growing every year.

The purpose of this article is to make a new discovery about this disease. Here are a few thoughts on the situation caused by this epidemic. In the first part of the article, as a hadith of blessing, there is a brief mention of how the defense system that Allah Almighty has given to the human body, how it performs its duty of protecting us from enemies. If a person considers his structure, then a feeling of gratitude to Allah will arise in his heart. It also summarizes some of the basics of coronavirus disease. In the second part, the emphasis is on how to deal with these disturbing situations with a believing character and a positive attitude.

There can be no peace and prosperity in a country where internal and external enemies are free to pursue their own interests. For the survival and integrity of the country, it is necessary that the police be ready to deal with the internal enemy and the army be ready to eradicate the external enemy. It is also important to know the difference between police and army, enemy and friend. Because if the police become the enemy of the citizens instead of the thieves, robbers and murderers and the army takes the path of interfering in the politics of the country by leaving the terrorists and the enemy forces, then it is not good for such a country. The same is true of the human body. The ability of the human body to protect itself from internal and external attacks is called the Immune System. Let's take a quick look at:

If an unwanted external element wants to enter our body, our skin does not allow it. If dust or any particle enters through the nose, it gets entangled in mucus and mucus, it does not enter and cause damage, then it is pushed out with the force of sneezing. Even if such particles fall into the eyes, they are not allowed to wreak havoc, soon tears seize them and push them out of their borders. When we eat, we eat useful things as well as many harmful things. There is a whole system in the stomach that breaks down all these things and separates the work things and removes the waste things from the body. Have you ever noticed that when a mosquito bites, 
etc., the area becomes slightly swollen, and a red mark appears? This is the reaction of the body's immune system to the chemicals introduced by the mosquito. Body cell soldiers do not leave China until the repair work is done. Even if there is a wound and bleeding begins, this system works and the blood clots at the wound site, so that there is no danger to the body from excessive bleeding.

For example, if a virus succeeds in entering the body, it will not be able to observe color rallies for a long time. The body's immune system immediately reacts and declares an emergency. You call it fever, cold and flu. When the body temperature is high, the virus has a problem in its terrorist activities and it is easy for the body's soldiers to find and dispose of them. The same is true of colds and flu. Runny nose is actually the result of this war, which is caused by harmful germs on the body's forces.

Not only that, but one of the best features of this body's immune system is that it remembers its old enemies. So when the same enemies attack again, they are easily chased away and no new bloody war is needed. This is the principle that scientists have used to make vaccines against many dangerous diseases. For example, when the smallpox epidemic broke out, it used to affect tens of millions of people, but now it is vaccinated. The vaccine is made from the (relatively less dangerous) smallpox found in cows. When a certain amount of it is delivered to the human body, the body's immune system fights it very easily and then these systems (or in certain words Memory Cells) remember this 'attack' and the next if ever smallpox. The virus also attacks, so the body easily defeats it.

A 'virus' is actually an infectious agent, which has an amazing ability to enter a living being and spread. Dmitry Ivanovsky, a Russian botanist who studied a disease of tobacco plants in 1979, said that the disease was caused by bacteria smaller than bacteria. They were later named viruses.

Is the virus itself alive or does it become infected when it enters a living creature? There is disagreement among scientists on this question. It can be said with caution that the virus shows clear signs of life when it enters an organism and starts its growth. It grows in such large numbers that, if left unchecked, endangers the very existence of an organism whose resources are gradually taken over by the parasitic virus. In addition to humans and animals, the virus seeks to control plants, even germs, such as invisible creatures to the human eye.

The epidemic that has plagued the world has been dubbed Corona Virus Disease 2019 (COVID-19). The virus responsible for the epidemic has been named Severe Acute Respiratory Syndrome Corona Virus 2 (SARSCoV-2) for its resemblance to the SARS virus. The following is a summary of the information in this regard: 
The virus was first detected in Wuhan, China. According to preliminary research by scientists, these viruses came from bats and snakes to humans. The virus is transmitted from humans to humans through respiratory droplets released through coughing or sneezing. The virus can survive three days on plastic or steel, one day on paper, and four hours on copper. Dry cough with high fever and difficulty breathing are some of the obvious symptoms that indicate corona virus infection. Hygiene and cleanliness can prevent viral infections. Even if there is a virus on human skin, it cannot start its reproductive process. But when a person puts his hand to the eye, nose, or mouth, the virus finds its way into the body. Therefore, special attention is being paid to hand hygiene. Similarly, if Islamic etiquette is observed while coughing and sneezing, the spread of infection can be largely prevented.

According to current statistics, $5 \%$ of people who were infected with the corona virus have recovered. Of those currently infected, only $3 \%$ are said to be in critical condition.

Statistics can be viewed at www.worldometers.info/coronavirus. According to experts, the death rate from this virus is two to four percent. The bad news, however, is that the corona virus spreads very fast. We know that two to four percent of a very large number is too large, so this issue cannot be taken lightly. The biggest danger is that if the corona virus spreads rapidly, the medical and healing systems of many countries around the world will not be able to bear this burden. To understand this, suppose that there are only ten hospitals in a city and an average of fifty patients in each hospital. If 5,000 people suddenly fall ill in this city, there will be famine in the city from hospitals, beds, doctors, nurses to medicines, because the medical system of this city has the capacity to care and treat only five hundred patients at a time. - Now these additional patients, even if they are suffering from a common disease, will suffer a great loss if they do not receive treatment (or at least do not receive treatment). But if the same 3,000 patients had been ill for a relatively long period of a month instead of a single day, all would have been treated and the damage to society as a whole would have been minimal. This is called flattening of the curve in the terminology. One of its main goals is to prevent the virus from spreading rapidly and to ensure that the country's medical system is not overburdened at the same time.

Why is there no awareness among the people to ask why our health system is so dysfunctional that we have in front of us human life on the one hand and human transport on the other hand, social relations, functioning of institutions, economic activities and other necessities of daily life. It's time to choose one? Experts have raised many questions about the lockdown 
strategy. According to the World Health Organization, asymptomatic transmission of the disease is very rare. That is the most viruses are transmitted by people, who have symptoms of the disease. There is little risk that seemingly healthy people will continue to transmit the virus. In such cases, testing the sick and quarantining them is the right strategy, not closing the whole country. "The economic consequences of such a complete lockdown would be dire," says Michael Osterholm (Regents Professor and Director, Center for Infectious Diseases Research and Policy, University of Minnesota). It is a delusion that all the people should stay at home and the basic needs of the people should be met. In such a situation, is our country moving towards a functional emergency? Does our government want to hide behind the Corona virus with its economic failures? Why isn't massive testing and quarantine strategies being adopted in exchange for lockdowns? If our country does not have the resources to adopt this strategy, then who is responsible for it? It's important to ask such questions before it's too late!

\section{Definition of Corona Virus:}

What is the corona virus? In Latin, the crown is called a corona, and the virus was given this name because it resembles a crown with pointed nails. The size of this virus is 06 to 0.14 and the average size is 0.125 microns.

Nowadays, print and electronic media (WhatsApp, Facebook and Twitter, etc.) are an important means of communicating information and news reaches all people instantly. But unfortunately the general attitude in this regard is irresponsible. Information is forwarded to others without research. On the contrary, sometimes false news is deliberately spread for various reasons, which leads to fear and panic. This is a very inappropriate attitude and the Prophet (PBUH) strictly forbade the transmission of any news without investigation and called such a person a liar.

One micron is one thousandth of a millimeter. It is spread from one person to another through breathing. Symptoms usually begin to appear about five days after entering the body, but can take up to two weeks. If a person spits mucus or saliva, the virus can live in it for many hours, sometimes even days.

\section{Symptoms of Corona virus (COVID -19):}

The symptoms of the disease are usually similar to the flu (influenza), but it is relatively high and spreads very fast. The virus stays in the throat for three to four days after entering the body and then enters the lungs or esophagus. The symptoms of the disease usually appear in the following order but this order is not necessary: In the beginning there is fever. Then comes a dry cough and difficulty breathing about a week later. In this 
disease, the symptoms of runny nose and sneezing are less than the common cold. Headache or general muscle pain can also occur.

\section{Dangers and precautions:}

Very young children and the elderly have more severe symptoms of the disease and it can be fatal. People with low immunity can be severely infected. Patients with diabetes, heart disease and other similar diseases are more likely to have a serious illness. Everyone should take the following steps to boost their immunity.

The most important thing is to get enough sleep. Try to go to bed early at night and not be busy after Isha prayers. Get up early in the morning and start the day with Fajr prayers. Allah has created the night for rest and the day for halal sustenance. It is now scientifically proven that a good night's sleep not only boosts a person's immune system but also helps prevent many other diseases.

Thus, it has been scientifically proven that people who are mentally confident, calm and have strong willpower also have stronger immune systems and increase the germicidal capacity of the body's immune system. Destiny and trust are the attributes of a Muslim, and the stronger and more effective these attributes of faith and the remembrance of Allah and related to it, the greater will be the power of resistance.

In addition, the diet should be high in protein. Milk, eggs, meat and pulses are high in protein. A few other things (such as vitamin $\mathrm{C}$, etc.) are also needed to boost immunity, which can be obtained from fresh fruits and vegetables, especially bananas, malts and green leafy vegetables. Avoid junk food such as burgers. They lower the immune system.

Wash hands thoroughly several times a day. It is better to use soap. Wash your hands for at least seconds and several times a day. If we perform ablutions five times a day and perform the obligatory prayers and at the same time wash our hands before eating and after going to the toilet according to the rules of Islam, then we will wash our hands at least eight to ten times a day. If we follow it as a Sunnah, then safety and reward will come together. When coughing or sneezing, cover your mouth with a tissue or handkerchief and wash hands immediately afterwards to prevent the virus from spreading. Put these items in the trash later and dispose of or burn them in a suitable place (municipal drums). If nothing is available, cover face with the sleeve of the elbow fold when you cough. Never cover your face with hands. Avoid touching eyes, nose and mouth after touching anything suspicious. Wash hands immediately if touched. Do not put dirty hands on face or face. This can cause the virus to enter your body. People who are coughing, sneezing or have a fever can get the virus out of their mouths and spread it into the air. Keep at least one meter, or three feet, 
away from such people. Don't go near such people. Stay home if you feel unwell. If you have a fever, excessive cough or difficulty breathing, consult a doctor immediately and follow their instructions. As the chances of the disease spreading are still high, avoid going to crowded places, unnecessary travel, markets, or gatherings. Apply a few drops on your hands every two to four hours. Do not bring the face so close that your breath is felt on the other's face. Drink plenty of water. Remember that if the virus enters the stomach from the throat, it dies due to gastric acidity and if it enters the lungs, it causes disease. If you have itchy or sore throat, gargle regularly along with the medicine. Not everyone needs to wear a mask. However, people who are more likely to get the disease, such as those in the health sector or those who suspect that they may be in contact with an infected person, should use a mask. There is no effective vaccine to prevent coronavirus and there is no drug to treat it, so precautions are the only way to prevent the disease.

Fear and terror of corona infection is causing people to suffer from social inequality and inconsistency, which creates a lot of psychological issues. Every one is upset, sad about these problems. The city, the streets and the bazaars are gloomy with sadness. The poor are worried, and so are the rich. Poor and day laborers are worried because they will not get wages due to lockdown, if they do not get wages then where will they eat. Rising inflation has made it difficult to eat two meals a day. The Prime Minister of Pakistan has laudably announced that Rs. 3,000 per month will be given to millions of workers for rations. Let's reduce some of the hassle. Praise be to God! Our welfare organization Customs Healthcare Society is also in the field. ${ }^{2}$

The Corona epidemic has affected countless men and women, young and old, poor and rich, and blacks and whites for the first time in their lives around the world. The following issues come to my mind when I think about the troubles, compulsions, difficulties and trials which I have seen among patients, friends and strangers face in the last few months. ${ }^{3}$

In the last few months, the physical and emotional distance between many patients and doctors has also been increasing. I don't know how many doctors have closed the doors of their streets, markets and hospital clinics. They now diagnose and treat their patients online. I advise patients to keep in touch with their loved ones, relatives and friends online. And attend zoom meetings regularly.

While Corona has imposed new restrictions on many jobs in the world, modern technology has also introduced us to new freedoms. Technology is helping to build relationships that didn't exist before. 
These days, many people of all races, languages and religions are hoping that scientists around the world will develop a coronavirus vaccine as soon as possible also practicing this in different countries so that people can be fully involved in the business of life again.

The coronavirus has forced people around the world to think about life from a new angle. When the world is healed by the Corona epidemic, humanity will not only have developed collective resistance and HERD IMMUNITY, but it will have reached the next level of collective consciousness.

\section{Corona Virus: Islamic Perspective:}

As Muslims, we believe that life and death are in the hands of Allah and it is not the Muslim way to be alarmed by such a situation. It is also necessary to seek treatment following the Sunnah. The Prophet (PBUH) forbade healthy people from entering the area of the disease and also forbade the people of that area from leaving. These measures are called quarantine in modern terms.

There is an important lesson for all, especially Muslims, in the current turmoil in the world. Allah says (interpretation of the meaning):

Corruption doth appear on land and sea because of (the evil) which men's hands have done, that He may make them taste a part of that which they have done, in order that they may return. ${ }^{4}$

Whatever good befalls you is from Allah and whatever evil befalls you is from yourself. $1 \mathrm{We}$ have sent you ' $\mathrm{O}$ Prophet' as a messenger to 'all' people. And Allah is sufficient as a Witness. ${ }^{5}$

Allah has given us another opportunity to learn a lesson so that we can focus on our deeds and turn to Allah. Do not waste this opportunity and sincerely repent from whatever is causing the wrath of Allah and ask for forgiveness as much as possible. Allah says :

We will certainly test you with a touch of fear and famine and loss of property, life, and crops. Give good news to those who patiently endure. who, when faced with a disaster, say, "Surely to Allah we belong and to Him we will 'all' return." They are the ones who will receive Allah's blessings and mercy. And it is they who are 'rightly ${ }^{7}$ guided. ${ }^{6}$

Today there is an atmosphere of fear everywhere. In such a situation, we have to face this test with patience and perseverance, relying on Allah. This is the success of both worlds for us.

It would be appropriate to mention here another aspect of the miracles of the Qur'an. In response to the criticism of the disbelievers in Surah Baqarah of the Holy Qur'an, Allah says:

Surely Allah does not shy away from using the parable of a mosquito or what is even smaller. As for the believers, they know that it is the truth 
from their Lord. And as for the disbelievers, they argue, "What does Allah mean by such a parable?" Through this 'test', He leaves many to stray, and guides many. And He leaves none to stray except the rebellious. ${ }^{7}$

The government of the day has taken several steps to prevent this epidemic. Everyone should act on it and do their part. This is the teaching of our religion. This difficult time also teaches us the lesson of turning to Allah and we should pay special attention to this and ask for forgiveness. At the same time, we should pray to Allah to give us the strength to overcome this epidemic and do good deeds. The following are some relevant essays in this regard:

Abu Hurairah narrated that: The Messenger of Allah (PBUH) said: "Whoever sees an afflicted person then says: 'All praise is due to Allah who saved me from that which He has afflicted you with, and blessed me greatly over many of those whom He has created, (Al-ḥamdulillāhi alladhī 'āfān̄ mimmabtalāka bihī wa faḍ̣alan̄̄ ‘alā kathīrin mimman khalaqa tafḍila)' he shall not be struck by that affliction."

O Allah, indeed, I seek refuge in You from the evil of what the wind brings ${ }^{9}$

Narrated Anas ibn Malik: The Prophet (PBUH) used to say: O Allah, I seek refuge in Thee from leprosy,madness, elephantiasis, and evil diseases. ${ }^{10}$

Narrated Abu Hurairah: A man who was stung by a scorpion was brought to the Prophet (PBUH). He said: Had he said the word: I seek refuge in the perfect words of Allah from the evil of what He created, he would not have been stung, or he said, It would not have harmed him. ${ }^{11}$

"There is no god 'worthy of worship" except You. Glory be to You! I have certainly done wrong." 12

In the same way, while taking all possible precautionary measures, we should recite Ayat ul Al-Kursi and Surah Al-Ikhlas, Surah Al-Falaq and Surah Al-Nas three times in the morning and evening after each prayer. In addition to this, there are many good deeds which we can not only overcome by overcoming these difficult situations with sincere faith, but they can also be a cause of Allah's pleasure for us.

Everyone has a responsibility to deal with this epidemic. He should not hesitate to do what he can. Doctors and other medical personnel should treat patients. Researchers should develop drugs and vaccines. Wealthy people should offer their wealth for scientific research, treatment and to meet the needs of the people. Everyone came forward to help the disabled and the elderly. Every human being should keep in mind that running to meet the needs of the people is one of the great deeds of nearness to God. 
According to the hadith, a man asked the Messenger of Allah (PBUH): Which of the people is most beloved to Allah? He said: "The one who is most beneficial to the people." 13

Islamic teachings call for the protection of human life and its protection from all forms of suffering. It is one of the high values that Islam has strengthened. Islam has given so much importance to the protection of human life that in case of oppression, Muslims are allowed to utter the word kufr. Allah says

Not those who are forced while their hearts are firm in faith ${ }^{14}$

Islam allows the sick and the traveler not to fast in Ramadan, so as to avoid severe hardship and harm. Allah says

But whoever of you is ill or on a journey, then 'let them fast' an equal number of days 'after Ramaḍân. ${ }^{15}$

These things are allowed despite the fact that they have to give up determination and good deeds. On this basis, it has been said in the first place that in order to save the people from the 'infection' of the corona virus, the prayers in the mosques should be stopped and the prayers should be offered in the houses.

There are some unanimous rules of Shari'ah: for example, Teasing will be removed, Illegal things become permissible in an unavoidable situation, Ease is given in case of hardship. In the current situation, the justification for stopping the performance of rituals in mosques can be argued from the following hadiths along with the above rules.

Narrated Abu Huraira: Allah's Apostle said: The cattle (sheep, cows, camels, etc.) suffering from a disease should not be mixed up with healthy cattle, (or said: Do not put a patient with a healthy person ). (as a precaution $)^{16}$

Doctors say with certainty that a person with the corona virus sometimes does not show symptoms for a long time. So he can transmit the virus to anyone he meets. This possibility is increased by people coming and going in mosques, standing in rows and prostrating different people in one place. Narrated Saud: The Prophet said, If you hear of an outbreak of plague in a land, do not enter it; but if the plague breaks out in a place while you are in it, do not leave that place. ${ }^{17}$

Attendance at mosques can be compared to the leave that the Prophet (peace and blessings of Allah be upon him) gave in the form of rain.

Narrated Muhammad bin Seereen: On a rainy day Ibn 'Abbas said to his Mu'adh-dhin, After saying, 'Ash-hadu anna Muhammadan Rasulullah' (I testify that Muhammad is Allah's Apostle), do not say 'Haiya 'Alas-Salat' (come for the prayer) but say 'Pray in your houses'. (The man did so). But the people disliked it. Ibn 'Abbas said, It was done by one who was much 
better than I (i.e. the Prophet (p.b.u.h) ). No doubt, the Jumua prayer is compulsory but I dislike to put you to task by bringing you out walking in mud and slush. ${ }^{18}$

There is no doubt that the danger of the virus and the hardships it causes are greater than the hardships of going to the mosque for prayers in the rain.

Abdullah bin Masud said: Persevere in observing these five times of prayer where the announcement for them is made, because they are from the paths of right guidance. And Allah, the Might, the Majestic, has laid down for his prophet (PBUH) the paths of right guidance. I have seen the time when no one stayed away from prayer except a hypocrite whose hypocrite was well known. I witnessed the time when a man would be brought swaying between two men till he was set up in the row (of the prayer). Every one of us has a mosque of his in his house. If you were to pray in your houses and stay from your mosques. You would abandon the Sunnah (practice) of your prophet, and if you were Abandon the Sunnah (Practice) of your Prophet, you would become an unbeliever. ${ }^{19}$

From this hadith, the jurists have argued that any fear about oneself or one's family is one of the excuses for leaving Jumu'ah or Jamaat. Going to the mosque can lead to self-infection and transmission to one's family, so one who does not attend Friday or congregational prayers is disabled.

Friday prayers are not allowed in homes through radio or television or loudspeakers or any other means of communication. By doing so, the Friday prayers will not be performed and whoever performs it in this way, the Zuhr prayers will not be canceled. This is the decision of the present day fatwa issuing bodies and associations. On this occasion, and many decades ago, all contemporary jurists have issued the same fatwa. Because Friday prayers is a devotional and devotional act of worship. It is paid in a certain Shariah way, without which it will not be valid. It has been paid in this manner and with these conditions and elements from the time of its obligation till the death of the Prophet (PBUH) and it has been paid in the same manner without any change. It is contrary to the Prophetic method to perform it in the house and it is a violation of the Prophetic guidance to take a new form for it, which will invalidate the prayers. Listening to Friday sermons and praying at home through any means of communication is not correct for several reasons:

$\mathrm{O}$ believers! When the call to prayer is made on Friday, then proceed 'diligently' to the remembrance of Allah and leave off 'your' business. That is best for you, if only you knew. ${ }^{20}$ 
This verse commands us to "run" for Friday. On this basis, the scholars have declared it obligatory to go to the mosque for Friday.

Aws bin Aws narrated: Allah's Messenger said to me: 'Whoever performs Ghusl on Friday, and bathes completely, and goes early, arriving early, gets close and listens and is silent, there will be for him in every step he take the reward of a year of fasting and standing (in prayer). ${ }^{21}$

Offering Friday prayers at home will not make it possible to follow these instructions of the Qur'an and Sunnah. Friday is obligatory in a specific way and for a specific purpose. Although scholars agree that Friday prayers are obligatory on Fridays or Zuhr prayers, there is disagreement among them as to which prayers are real and which are substitutes. The correct view is that Zuhr is original and Jumu'ah is different, because Zuhr became obligatory on the occasion of Isra 'and Jumu'ah became obligatory later. Therefore, if Friday cannot be established for any reason, then it will be returned to the original, that is, Zuhr. In many Muslim cities and areas, Muslims differentiate between Friday mosques and five-time prayers mosques. Therefore, they offer Friday prayers only in big mosques, not in small mosques. This benefit will not be obtained if the Friday prayers in the homes are declared valid through radio, mic or any other means of communication. The result of Friday prayers in the house at the sound of the mosque microphone will be that the slogan of Friday prayers will lose its significance and as a result, Friday and five daily prayers will not be arranged later. If the Friday prayers are valid in this case, then the five daily prayers will also be valid in the first place. There will be no need to build mosques like this. Only one small mosque will be built in each city, which can accommodate two or three people in addition to the imam. The rest of the people will pray on the microphone of the mosque in their homes and workplaces. Even more surprising would be that if the Masjid al-Haram and the time of prayers at them were the same, they would start praying behind the Imam of the Haram while watching television while living in their homes.

The jurists have stipulated that the Imam and the follower should be in the same place for the correctness of the follower in the prayer, and that the follower should know the movements of the Imam in such a way that there is no room for doubt and the follower should be unaware of the Imam's condition. Don't stay If he is ignorant, his prayers will not be valid. Similarly, the jurists have stipulated that there should not be much distance between the Imam and the Muqtada, for example, there should be no barrier, or a canal in which boats run, or there should be no obstacle that would allow the Muqtada to lead the Imam. It will prevent you from reaching (if he wants to go). Following the imam of the mosque through a 
microphone or any other means of communication while living at home will not fulfill these conditions. Therefore, according to the majority of jurists, such a prayer would not be valid. Their argument is from this hadith of the Prophet (PBUH).

Narrated Abu Huraira: The Prophet said, The Imam is (appointed) to be followed. So do not differ from him, bow when he bows, and say, Rabbana-lakal hamd if he says Sami a l-lahu liman hamidah ; and if he prostrates, prostrate (after him), and if he prays sitting, pray sitting all together, and straighten the rows for the prayer, as the straightening of the rows is amongst those things which make your prayer a correct and perfect one. $^{22}$

In Jumu'ah prayers, the main thing is to be devoted and restrained, that is, to perform it as the Prophet (PBUH) performed it. He never offered Friday prayers at home, neither did the Companions nor the people after him. Friday is one of the rituals of Islam. It requires it to be announced and paid for in a place where all Muslims can easily reach. That is why those who do not consider it a condition for Friday to have a mosque, also say that its payment should be in a place that is common to all Muslims. This condition will not be fulfilled if Friday prayers are offered in the house. According to the Hanafis, the condition for Friday prayers is general permission, that is, everyone should know where the Friday prayers are taking place. And the door is open for them to take part in it. This condition will not be fulfilled in the case of Friday prayers at home. Never in Islamic history have Friday prayers been offered in homes. Outbreaks appeared to be exacerbated during the Friday prayers in the mosques, and Friday prayers were stopped five times a day. The ancient jurists forbade Friday prayers in many mosques of a city and asked them to perform it in a big mosque. Its purpose was to express the unity of the Muslims. Then, according to him, why is it correct to recite Jumu'ah with three or four people in the house? In this case, the principle is to obey the orders of the city administration and the health department. If normal life is going on in the city, no case of Corona has come to light and no instruction of social distance has been issued, then there is no problem in offering prayers in the mosque.

It is important to follow the instructions of the city's health department. When gathering is stopped, one should stay at home and perform the five daily prayers with the family in congregation and the Zuhr prayers should be offered with the congregation instead of the Friday prayers. Prayers in mosques should be stopped to protect the lives of the people. 
In this case, the principle is to obey the orders of the city administration and the health department. If normal life is going on in the city, no case of Corona has come to light and no instruction of social distance has been issued, then there is no problem in offering prayers in the mosque. It is important to follow the instructions of the city's health department. When gathering is stopped, one should stay at home and perform the five daily prayers with the family in congregation and the Zuhr prayers should be offered with the congregation instead of the Friday prayers. Prayers in mosques should be stopped to protect the lives of the people. Allah says : Spend in the cause of Allah and do not let your own hands throw you into destruction 'by withholding'. And do good, for Allah certainly loves the good-doers. ${ }^{23}$

In these circumstances, it is better to suspend prayers in mosques and perform them at home. Congregational prayers are a definite Sunnah and the protection of human lives is obligatory. Thus, it is not correct to put the Sunnah before the obligatory. It is difficult to perform the prayers in the above manner, and what Allah has made easy is complicated. This is also contrary to the spirit of congregational prayers. This is because in the texts, the worshipers are commanded to stand close to each other in a row and it is forbidden to offer prayers alone behind a row. Even in this way, praying in mosques cannot protect people from aggression. Because coming and going in the mosques will mix them, different people will prostrate in the same place at different times, if they open the door of the mosque, they will touch the hands. Therefore, it is better not to offer prayers in mosques in this manner.

When a Muslim is in trouble, or in trouble, he runs to prayer, supplication and weeping before Allah Almighty. When the sun was eclipsed during the time of the Prophet (PBUH), the Messenger of Allah called it a sign of Allah and addressed his companions:

Narrated 'Aisha: In the lifetime of Allah's Apostle (p.b.u.h) the sun eclipsed, so he led the people in prayer, and stood up and performed a long Qiyam, then bowed for a long while. He stood up again and performed a long Qiyam but this time the period of standing was shorter than the first. He bowed again for a long time but shorter than the first one, then he prostrated and prolonged the prostration. He did the same in the second rak'a as he did in the first and then finished the prayer; by then the sun (eclipse) had cleared. He delivered the Khutba (sermon) and after praising and glorifying Allah he said, The sun and the moon are two signs against the signs of Allah; they do not eclipse on the death or life of anyone. So when you see the eclipse, remember Allah and say Takbir, pray and give Sadaqa. The Prophet then said, O followers of Muhammad! By Allah! 
There is none who has more ghaira (self-respect) than Allah as He has forbidden that His slaves, male or female commit adultery (illegal sexual intercourse). O followers of Muhammad! By Allah! If you knew that which I know you would laugh little and weep much. ${ }^{24}$

Just as solar eclipses and lunar eclipses are signs of God, which indicate His power, so plagues and all diseases are signs of God. Just as it has been commanded to offer prayers on the occasion of solar eclipse and lunar eclipse, so also on the occasion of epidemic etc. one should turn to Allah Almighty. It is prescribed to invite Muslims to prayers and supplications in times of trouble.

Scholars of principle and jurisprudence have stated that it is permissible to set a time for absolute acts of worship, such as staying up at night, remembrance and supplication, etc., if it is not believed that there is any special virtue in worship. Even if a person has the means to reach the nisab, but the year has not yet passed, Zakat can be paid in advance for a period of one year or more in view of the dire need of the people. In view of some credible expediency, it is correct to pay Zakat in advance before the end of the year, according to the Jumu'ah and most of the scholars.

Ali narrated: Al-Abbas asked the Messenger of Allah about paying his charity (Zakat) in advance before its time is due (by being in possession for a whole year), he permitted him to do that. ${ }^{25}$

Zakat is a financial right. The period for its payment has been fixed for the convenience of the Zakat payer. It can be removed prematurely. Just like a person takes a loan from someone for a certain period of time, he can repay the loan even before the maturity.

There is a misconception in the minds of some Muslims that the moral teachings of Islam relate only to the mutual affairs of Muslims. This is against the correct understanding of Islam. Islamic morality will be demonstrated to all human beings.

Abu Dharr said: The Messenger of Allah said to me: 'Have Taqwa of Allah wherever you are, and follow an evil deed with a good one to wipe it out, and treat the people with good behavior. ${ }^{26}$

It is prescribed to treat non-Muslims well, such as praying for them, treating them with compassion and helping them in various ways, but those who do so will be rewarded by Allah Almighty. Praying for someone is a good thing. This has been commanded in the Qur'an and Sunnah. Scholars agree that it is permissible for non-Muslims to pray for physical health and healing.

Narrated Anas: The Prophet said, None of you will have faith till he wishes for his (Muslim) brother what he likes for himself. ${ }^{27}$ 
The word 'brother' includes both Muslims and non-Muslims. Just as a Muslim wants health and healing for himself, so should he want it for other Muslims and non-Muslims.

It is not permissible according to shari'ah to feel constricted or hate a person who has contracted corona, or has contracted another epidemic. If a person sees someone in distress, distress, or disease, he should thank God that He has kept safe.

Umar narrated that: The Messenger of Allah (PBUH) said: "Whoever sees a person afflicted and say: 'All praise is due to Allah Who saved me from that which He has afflicted you with, and blessed me greatly over many of those whom He has created, (Al-ḥamdulillāhi alladhī 'āaānī mimmabtalāka bihī wa faḍ̂alanī 'alā kathīrin mimman khalaqa tafḍ̂ila)' then he shall be saved from that affliction for as long as he lives." 28

It is very possible that a person who is suffering from a problem has a higher status in the sight of Allah Almighty than a person who is safe from that problem.

Narrated Muhammad ibn Khalid as-Sulami: on his father's authority said his grandfather reported: He was a Companion of the Messenger of Allah (PBUH) said: I heard the Messenger of Allah (PBUH) say: When Allah has previously decreed for a servant a rank which he has not attained by his action, He afflicts him in his body, or his property or his children. Abu Dawood said: Ibn Nufail added in his version: He then enables him to endure that. The agreed version goes: So that He may bring him to the rank previously decreed from him by Allah. ${ }^{29}$

In case of diseases and especially in case of epidemic, the correct method is to follow the instructions of specialist doctors. Muslims and all others should strictly follow the instructions of health experts and the Government's advisory. The only valid method of spiritual healing is to pray to God for health and healing. He should also arrange prayers and dhikr to alleviate anxiety and grief. It is no secret that the Corona epidemic is spread by public outcry. As a result, a large number of people have contracted the disease, and many of them have died or become seriously ill, and in general have become a means of spreading the disease. Therefore, anyone who does this intentionally will be a sinner, even a sinner. That's why people should stay in their homes, not go out without urgent needs, and avoid meeting others. Anyone who violates these measures and restrictions and as a result becomes infected with the disease and transmits the disease to others, it is feared that his act So there is a fear that this act of will be on the level of 'murder on suspicion'.

Corona virus is a deadly virus that is spread by human interaction. If a person suffers from this disease and the other person touches it or touches 
something of it, then it can also affect him, he may even die. It is not permissible to go in or out of places where there is an epidemic. The reason for this is the protection of life, which is one of the purposes of Shariah. A Muslim must obey the orders of his city and the health department and not go out of his house unnecessarily. If there is an urgent need, he should follow all the precautionary rules and keep all the safety and security requirements in mind. It is clear from the sahih hadIth that it is obligatory to stay at home in times of epidemics.

If shaking hands and hugging is causing aggression, as doctors and experts have made clear, then shaking hands and hugging would be haram.

Funeral prayers are obligatory for the people. If some people do it, then all the people lose their obligation. Therefore, it will suffice for as many people as the law allows to offer funeral prayers, even if there are only three of them. However, Muslims who wish can offer funeral prayers in absentia, even if they do so alone.

As far as burial is concerned, the principle is that a Muslim will be buried where he died. The Companions were buried where they died. Similarly, the principle is that a Muslim should be buried in a graveyard reserved for Muslims. If there is any difficulty in this, he should be buried wherever possible, even if he has to be buried in a non-Muslim graveyard. In the Hereafter, man's deeds will be of use to him. Where is his burial? It will not benefit him at all.

Muslim religious organizations should do their best to understand the importance of burying the dead in the eyes of Muslims. And how much anxiety will be in burning their bodies? Explain this and put pressure on the concerned departments not to decide to burn the bodies.

\section{Conclusion:}

The number of people infected with the corona virus in Pakistan is increasing day by day. Although the government has taken timely precautions and security measures, the death toll from the virus is much lower than in other countries, but the reality is that the lockdown that has been going on for weeks in most parts of the country. The economy has been hit hard. Due to the closure of various industries and restrictions on transportation, about 19 million people have lost their jobs, 70\% of whom are from Punjab province. ${ }^{30}$ Among those most affected by the lockdown restrictions are employees of small and medium-sized enterprises, businesses and companies (SMEs) and hard-working daily wage earners. The government has allocated Rs 144 billion under the Ehsas Emergency Cash Program to provide financial assistance to the unemployed. The amount will be distributed to more than 80 million people in phases. The Ehsas program is undoubtedly a welcome step. However, this is not a 
permanent solution to the problem. Instead of relying on external debt, the government should strive for self-sufficiency and create employment opportunities for the people by developing education, construction, energy, agriculture, health and transport. There is an opportunity for improvement in every issue. The government of Pakistan should try to change the problem of corona virus from an opportunity for collective and public welfare.

\section{Recommendations:}

1. The government's first priority should be to stabilize the economy in the light of various economic indicators during Covid 19.

2. The government of Pakistan spends only 2 to $3 \%$ of its annual GDP on the health sector, despite its large population and inability to afford treatment. Europe and the United States are also suffering from a shortage of protective equipment (PPE) due to the rapid spread of the corona virus. The Government of Pakistan should ensure that medicines and medical devices and facilities such as masks, protective clothing and ventilators are manufactured locally in accordance with international standards. This will not only make Pakistan self-sufficient in its medical and health-related needs, but also create countless employment opportunities. The healthcare sector requires specialized education, skills and expertise. The quality of education of the people will also increase and their skills will also be burnt.

3. The SBP should further reduce interest rates to restore investor confidence and stabilize the economy.

4. The government should use the millions of people who lost their jobs as a result of the lockdown to plant trees. It will also significantly reduce the harmful effects of climate change and provide a source of livelihood for the people.

\section{References:}

\footnotetext{
${ }^{1}$ Xixing Li, Weina Cui and Fuzhen Zhang, Who Was the First Doctor to Report the COVID-19 Outbreak in Wuhan, China? (https://jnm.snmjournals.org/content/61/6/782), Accessed date, March 17, 2021.

2 Dr. Asifa Mahmood, The social and psychological effects of the terror of corona infection, (Retrieved from https://www.express.pk, March 26,2020) / SPETCI, para, 2

3 Khalid Suhail, Corona epidemic and psychological problems, https://www.humsub.com.pk, 11,11,2020

${ }^{4}$ Al. Quran. Surah Rum, 30:41

${ }^{5}$ Al. Quran. Surah, 4:79

${ }^{6}$ Al. Quran. Surah Al Baqarah,, 2: 155-157

${ }^{7}$ Al. Quran. Surah Al Baqarah,, 2:26

${ }^{8}$ Tirmazi, Abu Isa Muhammad bin Issa, Jami at Tirmidhi, Chapters On Supplication,3432

${ }^{9}$ Ibid, 3520
} 
${ }^{10}$ Abu Dawood, Sunan Abu Dawood, rayer (Kitab Al-Salat): Detailed Injunctions About Witr Hadith No. 1554

${ }^{11}$ Ibid, Chapter 29, Medicine (Kitab Al-Tibb), Baab, Zabiha Ke Ihkaam O Masail, 3899

12 Surah Al Anbia, 21:87

${ }^{13}$ Al Mutqi al Hindi, Kanz ul Amal, Kitab al Muaiz al Riqaq, Hadith No, 44154, Maktaba al Shamila

${ }^{14}$ Al. Quran. Surah Nahl, 16:106

${ }^{15}$ Al. Quran. Surah Al Baqarah, 2:184

${ }^{16}$ Bukhari, Sahih Bukhari, The Book Of Medicine,Dawa Aur Elaaj Ke Bayan Main,5771

${ }^{17}$ Ibid, The Book Of Medicine, Dawa Aur Elaaj Ke Bayan Main, 5728

${ }^{18}$ Ibid, Chapter 12, The Book Of Al-Jumuah (Friday),Baab,Jumah Ke Bayan Main

19 Abu Dawood, Sunan, Chapter 2, Prayer (Kitab Al-Salat), Baab, Taharat Aur Us Ke Ehkaam O Masail

${ }^{20}$ Surah Al Jumu'ah, 62:9

${ }^{21}$ Tirmazi, Al Jame al Sahih, Chapter 5,The Book On The Day Of Friday, Baab, Nawafil Aur Sunnaton Ke Ehkaam O Masail, 496

${ }^{22}$ Bukhari, Sahih Bukhari, Chapter 10,The Book Of Adhan, Baab, Azaan Ke Masail Ke Bayan Main 722

${ }^{23}$ Surah Al Baqarah, 2:195

${ }^{24}$ Bukhari, Sahih Bukhari, The Book Of The Eclipses, Sooraj Girhan Ke Mutaliq Bayan, 1044

${ }^{25}$ Tirmidhi, Jami At Tirmidhi, The Book On Zakat, Witr Ke Firoyi Ehkaam O Masail,678

26 Ibid, Chapters On Righteousness And Maintaining Good Relations With Relatives,Khaane Ke Mutaliq Ehkaam O Masail, 1987

${ }^{27}$ Bukhari, Jami, The Book Of Belief (Faith), Emaan Ke Bayan Main, 13

${ }^{28}$ Tirmadi, Jami, Chapters On Supplication, 3431

29 Abu Dawood, Sunan, Funerals (Kitab Al-Jana'iz), Ghulam Ki Azadi Ke Ehkaam O Masail, 3090, Accessed date, March 17, 2021.

${ }^{30}$ Muhammad Asif Ehsan, Coronavirus: Economic Challenges Facing Pakistan https://urdu.alarabiya.net/politics/2020/05/07/ Accessed date, March 17, 2021. 